\title{
IMPLICATIONS OF COMPUTER-AIDED LEARNING IN ELT FOR SECOND LANGUAGE LEARNERS AND TEACHERS DURING COVID-19 \\ Faiza Saeed $^{1 *}$, Aniqa Rashid ${ }^{2}$, Wajiha Saleem ${ }^{3}$, Muhammad Sufyan Afzal ${ }^{4}$
}

${ }^{1 * 3,4}$ Lecturer, National University of Modern Languages (NUML) Islamabad, Faisalabad Campus, Pakistan; ${ }^{2}$ Assistant Professor, National University of Modern Languages (NUML) Islamabad, Faisalabad Campus, Pakistan.

Email: ${ }^{1 *}$ faizasaeed@ numl.edu.pk, ${ }^{2}$ anrashid@ @uml.edu.pk, ${ }^{3}$ wajihasaleem@numl.edu.pk, ${ }^{4}$ sufyan.afzal@numl.edu.pk Article History: Received on $19^{\text {th }}$ April 2021, Revised on $28^{\text {th }}$ June 2021, Published on $30^{\text {th }}$ June 2021

\section{Abstract}

Purpose of the study: The primary purpose of this research study was to get detailed insights about numerous aspects of the online ELT for second language learners and teachers in Faisalabad.

Methodology: Our study was based on an online survey. Respondents were students and teachers of the English department from different universities in Faisalabad. Data was collected and analyzed to find answers to our research questions. Other characteristics like focus, comfort, understanding, communication, and expense pinpoint the differences between online and physical ELT methods.

Main Findings: We found that students and teachers most commonly faced internet connectivity and audio-visual issues. The overall opinion of students about teachers was encouraging. However, teachers claimed that students were not that much serious in online classes. Online ELT has improved the technical capabilities of respondents, and it has made them proficient in using smartphones, online storage, word processing, and computer troubleshooting. Faculty respondents showed interest in learning new tools despite the burden faced and psychological fears. Finally, social media and solution-oriented discussion forums can prove effective and efficient in addressing future pandemic outbreaks.

Applications of this study: This study provided us with valuable insights that can help design an effective online educational framework for efficient and result-oriented English language learning.

Novelty/Originality of this study: Our study explored faculty and students' psychological and technological readiness at postgraduate institutes to cope with future pandemics.

Keywords: ELT, CALL, Online Education, Second Language Learners, Education in Pandemic.

\section{INTRODUCTION}

The English language plays a vital role in today's modern world as it is involved in communication in every field of life, including education and business. Due to the ongoing pandemic situation, business activities are reducing, and people working in the private sector lose their jobs. Moreover, young graduates also face difficulties in finding employment in developing countries like Pakistan. As a result, freelancing and digital marketing are getting boom these days. English is a global language used in media, the internet, and international communication. So, the importance of English Language Teaching (ELT) cannot be ignored.

People worldwide use it as a 'common language' to share their ideas, express their thoughts, and communicate with others. Although the English language is being taught as a second foreign language in all academic institutions throughout Pakistan, yet students cannot get the most out of it in professional life. English is a universal communication language used to communicate textual, visual, audio, and infographic information globally. To use English as effective for education purposes importance of expressions, emotions, and fluency in student education must be given chief priority (Unsworth and Mills, 2020).

All institutions are making maximum efforts to improve the English learners' language competence to grab many opportunities to make progress personally and professionally. English language teachers and curriculum developers are also making consistent efforts to improve English language teaching in Pakistan. During the past two decades, an immense increase in student enrollments resulted in upgrading old colleges and constructing new ones in China. For teaching English as Foreign Language (EFL), job opportunities for English teachers have increased to deal with rapidly growing student strength (Zhiyong et al., 2020).

The current prevailing COVID-19 situation has created a massive impact on both teachers and learners. The Working dynamics of our educational institutes, teachers, and students have changed entirely. Virtual classrooms replace classrooms, and computer-aided tools have taken traditional white or blackboards. For how much time this situation continues is not easy to predict (Jena, 2020).

Since the 1990s, computers are being used in our country computers for different purposes, but smartphones have revolutionized the world and provided a gadget equipped with powerful apps. From entertainment to business and business to education, it has all sorts of apps to cope with different circumstances. However, it is also a fact that not everybody is equally technical or proficient in using computers and smartphone apps (Asad et al., 2020).

Computer-Assisted Language Learning (CALL) provides opportunities to teachers in providing resources to students in 
the quickest possible way in Thailand. Language instructors can use videos, tutorials, animations, and infographics to enhance the learning capabilities of students, which can increase student's interest and knowledge. However, this is effective only to some extent, and using CALL to aid traditional language teaching is more beneficial. Teachers need to ensure that technological tools are readily available to the students and students are familiar with their usage (Khamkhein, 2012).

During the COVID-19 pandemic, a survey was conducted on 100 respondents on two popular universities in the South of Punjab. These universities included Khwaja Fareed University of Engineering and Technology (KFUET) and Islamia University Bahawalpur (IUB). All the respondents were from the English department. 46\% of students found that teachers were not technically strong to handle virtual classes. Another alarming thing was that $47 \%$ claimed unwanted interruptions during virtual courses due to technical reasons (Shahzad et al., 2020).

We believe that the issues faced by both secondary language teachers and learners pose huge barriers to language learners and instructors. New strains of the COVID-19 virus came into our knowledge at least twice in the year 2020. However, to provide the best ELT to our young students, we need to explore ELT methods in the context of COVID-19.

Our research explores various dimensions of modern English language teaching done via computing technology these days. By examining online education during this pandemic, we came up with suggestions that can improve second language learners' English language education process. Our recommendations can assist learners and speakers in being successful members of an international English-speaking community.

During 2000-2010, there is no significant research contribution on topics integrating technology and ELT. The highest number of publications on such issues was 12 in 2016, which lowered to 4 in 2017. In comparison to China, less attention was paid to smartphone technology in Saudi Arabia. During the last decade, most research articles used questionnaires for data collection (Nawaila et al., 2020).

Section 2 explores the significance of the English language in our modern world. How COVID-19 and Information Technology (IT) has transformed the traditional educational system in Pakistan is explored in section 3 . In section 4 of this paper, we have provided the research questions of this study, while section 5 explores different studies conducted worldwide. Finally, our research methodology and findings are discussed in sections 6 and 7, respectively.

\section{SIGNIFICANCE OF ENGLISH LANGUAGE}

English is a universal language as it is understood and used worldwide. Internet today has emerged as an immense source of information. The majority of the websites, blogs, and even search engines use English as their primary language. Social media websites, for instance, Facebook, Twitter, and Instagram are also using English as a basic language. Although these platforms provide multi-language capability and automated translators, most users prefer the English language version. E-Commerce is getting popular quickly with the advancement of the internet and business technology. All the popular E-Commerce platforms like Amazon, AliExpress, and Daraz also use English as their primary language.

People, especially students in developing and developed countries, are highly focused on freelancing due to the job saturation in respective countries. Moreover, the number of unemployed educated persons is increasing alarmingly during this pandemic. So, switching to freelancing is a promising dimension to earn a livelihood. Most clients on freelancing platforms like Fiverr, Upwork, and People Per Hour are native English people. The primary mechanism to deal with a client is written communication, although some platforms support video conversation. No matter what the scenario is, a freelancer should communicate clearly and precisely with their client to achieve his goals.

Digital marketing has got boom since 2013, and it uses sophisticated technology for marketing products and services. Digital marketing supports bidirectional communication between seller and buyer. Both can use various communication channels, including social media, website forums, E-Mail, and chatting. Digital marketing provides an opportunity to reach a global audience with the help of search engines like Google (Sathya, 2017). The language understanding of students depends upon the effectiveness of ELT methods used by the course instructors. 58\% of teachers and $63 \%$ of students preferred the Grammar Translation Method (GTM) over the direct method and observed that this ELT method was more effective and beneficial (Shah and Saeed, 2015).

Moreover, applications of the English language are not limited to marketing or business. There are hundreds of areas that direly need command over this language. The majority of job qualifying tests, interviews, and tasks are English-oriented. Even on jobs, the English language is being used for official correspondence. Curriculum developers also prefer the English language for textbooks. One of the core reasons is the ease and comfort of this language. English writing skills are required for different scenarios. Polishing students' writing skills, traditional teaching methods need certain refinements that enable teachers to understand students' issues properly. Teacher interaction, motivation, and knowledge are key pillars to achieve this goal (Shegay et al., 2020).

\section{ROLE OF INFORMATION TECHNOLOGY IN ONLINE EDUCATION}

COVID-19 has changed the entire dynamics of Pakistan and the rest of the world. A huge majority of people have switched to online shopping for implementing social distancing in true meaning. During the first wave in 2020 , 
telemedicine took trend as medical professionals were either busy dealing with COVID patients or practicing isolation principles in true letter and spirit. The usage of online consultation apps like Oladoc and Marham has also increased to a great extent.

MARHAM app is quite popular in Lahore and Karachi as the number of registered medical practitioners is, 495 which is promising. MARHAM has a dedicated mobile app for its users that serves online video consultations, Apart from social media handles. On the Facebook page, $43.23 \%$ of the issues were raised by female users, and this shows that this telemedicine app is quite popular among young females. The majority of female users belong to the age group having an age range from 18 years to 34 years (Ittefaq and Iqbal, 2018).

COVID-19 is an extremely lethal and quick-spreading virus. Patients with certain underlying conditions like asthma, heart, diabetes, and immunodeficiency are at greater risk of getting seriously ill. Telemedicine can assist such patients and provide an opportunity to get examined by specialists' doctors via two-way audio/video conference. In this way, telemedicine can fulfill patients' needs in a cost-effective and timely manner that strictly obeys social distancing principles (Portnoy et al., 2020).

As with other disciplines, the education sector is also severely affected by this pandemic. Keeping in view of its disasters, all the public and private sector institutions are closed for on-premise classes. Institutes have switched to the online education model, which has many challenges for both students and teachers. Technological gadgets and apps have taken the place of physical classrooms. To assist academic activities, platforms like Google and Microsoft are constantly opening new avenues. There are also third-party apps like Zoom are available in the digital world. Moreover, these organizations are improving their services and functionalities.

For advancing technology, science, and arts, English is considered critical as it is the first foreign language. While multimedia and CALL technology is an emerging trend in various countries, including Pakistan, China started emphasizing CALL in 1978 to enhance students' concentration by making topics look interesting (Asrifan et al., 2020).

A case study conducted at Mizoram University explored different modes adopted by teachers and students during the COVID-19 pandemic. $45 \%$ of faculty members preferred using Zoom, Google Meet, and Skype for online education. In addition to this, $100 \%$ of respondents designated WhatsApp or Telegram as the most promising tool for communication. Half of the teacher respondents opted for YouTube to upload recorded lectures (Mishra et al., 2020). Hence, the importance of using online tools can't be ignored in this era. We've categorized these tools into four categories. Let us briefly discuss some popular tools used in Pakistan since the first wave of this pandemic.

\section{Generic Communication Tools}

Teachers and students use these sorts of tools to communicate various academic matters. Teachers use such tools to make certain announcements and notices. On the other hand, students discuss their problems with faculty via these groups. Some of the popular platforms to serve this purpose are:

- WhatsApp

- Facebook groups

- E-Mail

- Google classroom

- Instant messaging

\section{Classroom Management Tools}

Effective management of the classroom is of chief importance. Teachers share lecture handouts, recommended books, PowerPoint slides, and other related courses using these tools. In addition to this, these tools help the faculty to manage the attendance records as well. Quiz and assignment submissions can be easily made via classroom management tools. Some popular tools are:

- Google classroom

- Dedicated Learning Management System (LMS)

- Moodle

\section{Virtual Classroom Tools}

Face-to-face communication is no doubt the best method to share ideas. During this pandemic, the chances of spreading the virus increase in the absence of social distancing. Hence, video conferencing is the best way to achieve this objective. Google Meet, Zoom, and Microsoft Teams have commonly used tools for conducting virtual classes. All of these tools offer screen sharing, chatbox, annotations, and file sharing as add-ons. Apart from online meeting tools, video-sharing platforms like YouTube and Daily Motion are also great sources for sharing academic information, including video 
tutorials, lectures, and animations.

YouTube can be used as an effective technology platform for teaching art students. YouTube can help teachers to find and share some exciting material with students. On the other end, students can use this huge video library for learning new skills. Integrating information technology with education can enhance both art teachers and students (DeWitt et al., 2013). Tools that can be used for conducting virtual classes include:

- Google Meet

- Zoom Meetings

- Microsoft Teams

\section{Assistive Tools}

During this pandemic, services offered by various tools other than those discussed above are worthwhile. Word processing (MS-Word) and presentation (MS-PowerPoint) software are in the limelight. These have smoothened the lecture delivering process to a great extent. Apart from these, there are certainly other tools as well. Various institutes have adopted recorded lecture schemes as well,1 where faculty provides pre-recorded lectures to students. Camtasia and Filmora are the big names. These are high-and tools to edit and publish lecture videos. A huge population of faculty also uses third-party mobile apps to serve this purpose.

Students can pause, play and replay a pre-recorded lecture according to their convenience; this enables students to grasp the knowledge without any pressure or time constraint. A short case study was conducted on a small sample of business administration students at Yonsei University Korea. 53.8\% of students preferred pre-recorded lectures due to this reason, while only $7.7 \%$ were favoring live video conference lectures on Zoom (Islam et al., 2020). Last but not least, online storage providers like Google Drive and Dropbox are also being used widely. Organizing, sharing the files, and troubleshooting via these tools demand skills as well as experience.

\section{RESEARCH OBJECTIVES}

The main aim of this study was to get answers and insights about various issues faced by both students and faculty, specifically in ELT. Table 1 shows multiple research questions considered as our study parameters. Our research questions were abstract; hence, we sub-divided the main questions into various sub-questions to get objective answers and detailed insights. The questions are provided in Annexure-A.

Table 1: Research Questions of this Study

\begin{tabular}{ll}
\hline RQ \# & Question \\
\hline 1. & What are the key differences between online and physical ELT methods given to teachers and students? \\
\hline 2. & What are the major technical difficulties faced by faculty as well as students in the online ELT method? \\
\hline 3. & What was the assessment of the students about teachers during online ELT? \\
\hline 4. & What was the assessment of the teachers about students' learning outcomes? \\
\hline 5. & How has information technology benefitted the students as second language learners? \\
\hline 6. & How has information technology benefitted teachers during a pandemic? \\
\hline 7. & How much our educational system is prepared for using computer-aided tools? \\
\hline 8. & How to utilize information technology effectively for ELT during future pandemics? \\
\hline
\end{tabular}

\section{LITERATURE REVIEW}

Ulla et al. (2020) explained that despite research on Mobile Assisted Language Learning (MALL) and ELT, the area involving the integration of Information and Communication Technology (ICT) in ELT remained a little unexplored. This study was focused on understanding different teaching practices employed by teachers in teaching EFL with the help of internet-based applications in Thailand. Some popular tools used by EFL teachers included social media groups, YouTube, and Google forms.

Quinn and Clark (2015) conducted a study and explored the main factors that support education via pre-recorded lectures. $81 \%$ of participating respondents liked this mode of education due to many reasons. Majority of students considered viewing pre-recorded video lectures alone. Students were also able to develop a pattern to watch these lectures. Convenience was one of the leading factors because this mode freed students from the bound of time or location. The ability to replay lessons helped students to gain a deep understanding of the subject matter. Pre-recorded lectures provided students ample time to take detailed notes as well as manage lecture breaks.

Hadgu et al. (2016) compared live lectures and pre-recorded lectures by assessing students' exam performance in both these groups. Studied constituted various groups of students designated as Live Lecture (LL) and Pre-Recorded Lecture (PRL) and performance of each group was assessed based on different types of questions including Memory Questions (MQ), Comprehensive Questions (CQ) and. There was no significant difference between both groups in terms of correct answers. However, the right answers to CQ by the LL group were significantly higher than the PRL group. The PRL 
group showed remarkable performance in answering MQ and answered 80\% of questions correctly. On the other hand, the LL group answered $72 \%$ of memory questions correctly.

Bakar (2007) elaborated that the first smart school was established in Malaysia in 1991, and this enabled the integration of Information Communication Technology (ICT) in ELT for teachers and students. The use of ICT increased the interest of students in the subject, and students became self-motivated. Students were more engaged in classrooms and started to use the English language practically while doing various activities.

Qureshi et al. (2012) surveyed to identify various technical barriers preventing the realization of online education in Pakistan. $62 \%$ of students believed that the latest hardware and software were available in the university. Additionally, $53 \%$ responded that internet services at the campus were fast, and according to $56 \%$ of the respondent, high-speed internet was also available outside the campus. Downloading material from the internet was recognized as a quick way to access information by $54 \%$ of students. Only 350 respondents from Iqra University Islamabad, Pakistan, participated in this study.

Raza et al. (2017) conducted a study to determine the influential factors critical for implementing m-learning in Pakistan's higher education institutes. Both faculty and students were enthusiastic about m-learning, but students' readiness was more significant. However, the teachers' attitude towards m-learning adoption was equally important.

Rahim et al. (2011) explored the integration of Information and Communication Technology (ICT) in the Gilgit area of Pakistan and conducted interviews on twenty-six schools. Staff in the majority of institutes were using the computer only for office work. The percentage of teachers using ICT for education was found to be on the lower side. In some schools, staff was not aware of computers; however,r this was extremely low in numbers. Internet availability was not provided to faculty. Hence, the unavailability of technology was identified as the main hindrance in integrating ICT and education in mountain areas.

Milal et al. (2020) suggested training to be essential for professional skills development for English language teachers. Effective training programs enabled teachers to cope with common problems, and teachers learned new methods of ELT. The training program also improved communication and organization of teaching material. Additionally, classroom management became more effective, and students' behavior got better.

$\underline{\text { Schurz and Coumel (2020) }}$ explained the key differences of ELT methods in different European countries, mainly Sweden, France, and Austria. ELT in Austria was more focused on grammar in comparison with Sweden and France. Sweden ELT methods included fluency practices more.

Pervaiz et al. (2021) discussed the importance of English writing skills in academics and professional careers. In Pakistani schools, faculty had to follow the curriculum strongly. Moreover, the syllabi taught in the private and public sectors were different. Classroom ELT techniques played a vital role in the overall grooming of students in learning the art of communication skills.

Sultan and Hameed (2020) surveyed the students of Pakistan Military Academy (PMA) to find out motivation towards curriculum, integrated with local and global cultures. As second language learners, more than 50 percent of respondents were interested in learning about the UK and USA cultures. In comparison, more than 60 percent were attracted to learning about the culture of other English-speaking countries. A very low number of faculty asked students to watch cultural movies or videos.

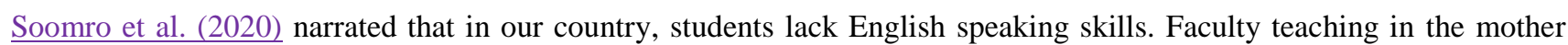
language could be one of the reasons. More than of $60 \%$ teachers believed that professional training institutes could solve this issue. Additionally, only 33 percent not teachers employ audio-visual techniques for ELT, which was surprising because most schools in Pakistan don't have multimedia classroom facilities.

Irfan et al. (2020) elaborated that the English language was focused at school levels to build and polish students' listening, speaking, reading, and writing skills. In Pakistan, finding well-trained teachers was a dilemma, especially in villages and other far areas. The majority of university graduates were not proficient in these four basic skills. The lack of using audiovisual aids was the least focused method when compared with other methods.

Kosten (2020) described that CALL posed serious problems called English problems in countries with mono-lingual educational cultures. During the past decade, most of the research was conducted on bilingual and multilingual CALL. Many CALL tools offered mono-lingual support, specifically English. Offering multilingual support could eliminate the English problem in mono-lingual countries.

Enayati and Gilakjani (2020) explained for effective teaching of EFL; vocabulary played a critical role. Unfortunately, less concentration and time was spent by teachers in focusing on vocabulary learning. The use of CALL could dramatically improve students' ability to speak words properly. A study was conducted on EFL learners in Iran, and researchers found that the use of Tell Me More (TMM) could develop and enhance learners' speaking abilities. 


\section{RESEARCH METHODOLOGY}

To answer our research questions, we've conducted this exploratory study in various public and private sector universities in the Punjab province. Data was collected through questionnaires and analyzed statistically. Below is our detailed research methodology.

\section{Research and Instrument Design}

We have adopted quantitative research methodology as it is an extremely effective fact-finding technique. For this, we collected data by using a questionnaire instrument. To make this study more convenient for respondents, separate questionnaires were designed and shared with participants. Each questionnaire was divided into various sections. Detailed instructions were written to assist respondents with each unit in collecting different information, including respondent demographics. The questionnaires were designed using Google Forms, and a 5-point Likert scale was used according to the suitability of questions.

\section{Participants of this Study}

We considered faculty and students of the department of English from various public, private and semi-government sector universities in Faisalabad. Teachers and students of schools and colleges were not taken into account. Forty teachers and 174 students participated in this study.

\section{Data Collection}

Questionnaires were shared through various mediums, including E-Mail, social media, and WhatsApp groups. Teachers were also requested to furnish it to students for error-free data collection. As discussed earlier, the questionnaire was selfexplanatory, and for the sake of convenience, an instruction manual was also provided to the respondents. Responses were received online in the form of a Google sheet.

\section{Data Analysis}

After collecting the responses, we removed anomalies. Data reliability was also assessed through the Cronbach alpha method, which is popular among researchers for ensuring that data is consistent internally (Taber, 2018). Reliability percentages for teachers' and students' datasets were $75.53 \%$ and $75.57 \%$, respectively. This ensured the integrity and reliability of collected responses. As all the questions were close-ended ones, SPSS was chosen to perform statistical analysis on the data. Results along with graphical representations and interpretations are given in the coming section.

\section{RESULTS \& DISCUSSION ON FINDINGS}

Before moving to the detailed insights of this study, let us give you an overview of respondent demographics. Table 2 shows the precise demographics of our respondents.

Table 2: Respondent Demographics

\begin{tabular}{lll}
\hline Respondent & Characteristics & Measure \\
\hline \multirow{2}{*}{ Students } & Total: & 174 \\
\cline { 2 - 3 } & Degree Level: & BS (76.4\%), MA (22.4\%), M. Phil (0.6\%), Others $(0.6 \%)$ \\
\cline { 2 - 3 } & University Sector: & Public (40.2\%), Private (3.4\%), Semi-Government $(56.3 \%)$ \\
\hline \multirow{2}{*}{ Teachers } & Total: & 40 \\
\cline { 2 - 3 } & Designation: & Lecturer (92.5\%), Assistant Professor (7.5\%) \\
\cline { 2 - 3 } & University Sector: & Public (47.5\%), Private (30\%), Semi-Government $(22.5 \%)$ \\
\cline { 2 - 3 } & Mean Teaching Experience: & 7.01 Years \\
\hline
\end{tabular}

\section{Key Differences between Online and Physical ELT Methods}

Table 3 enlists different questions that helped us understand the differences between online and physical ELT classes in view of both respondent categories.

Table 3: Difference between Online and Physical ELT

\begin{tabular}{lll}
\hline $\begin{array}{l}\text { RQ1: What are the key differences between online and physical ELT methods given to } \\
\text { teachers and students? }\end{array}$ & \\
\hline Respondent: Students & Agree & Disagree \\
\hline Sub-Questions & 68 \\
\hline $\begin{array}{l}\text { In attending lectures, my focus was better in online classes as compared to } \\
\text { physical classes. }\end{array}$ & 68 & \\
\hline $\begin{array}{l}\text { My understanding of lecture matter was better in online classes as compared to } \\
\text { physical classes. }\end{array}$ & 71 & 67 \\
\hline I was more comfortable covering the syllabus in physical classes. & 125 & 17 \\
\hline
\end{tabular}




\begin{tabular}{lll}
\hline I was more active in physical classes. & 134 & 17 \\
\hline Communication with teachers was easy. & 141 & 16 \\
\hline The E-classroom environment was favorable for learning. & 96 & 31 \\
\hline Online classes caused extra expenditure for my regular work. & 98 & 44 \\
\hline Respondent: Teachers & Agree & Disagree \\
\hline Sub-Questions & 17 & 13 \\
\hline $\begin{array}{l}\text { In delivering lectures, my focus was better in online classes as compared to } \\
\text { physical classes. }\end{array}$ & 10 & 21 \\
\hline $\begin{array}{l}\text { My understanding of student issues regarding lecture matter was better in } \\
\text { online classes as compared to physical classes. }\end{array}$ & 10 \\
\hline I was more comfortable covering the syllabus in physical classes. & 31 & 3 \\
\hline I was more active in online classes. & 15 & 17 \\
\hline Communication with students was easy. & 18 & 17 \\
\hline The E-classroom environment was favorable for teaching. & 17 & 16 \\
\hline Online classes caused extra expenditure for my regular work. & 31 & 7 \\
\hline
\end{tabular}

All the sub-questions were used objectively to highlight the key differences felt by respondents during the journey of online education in COVID-19. Focus, understanding, comfort, activity, communication, environment favorability, and teaching expenses were major factors that we considered to develop the critical difference between online and physical ELT mode for second language learners and teachers. All these factors, along with the opinion of respondents, are shown in Figure 1.

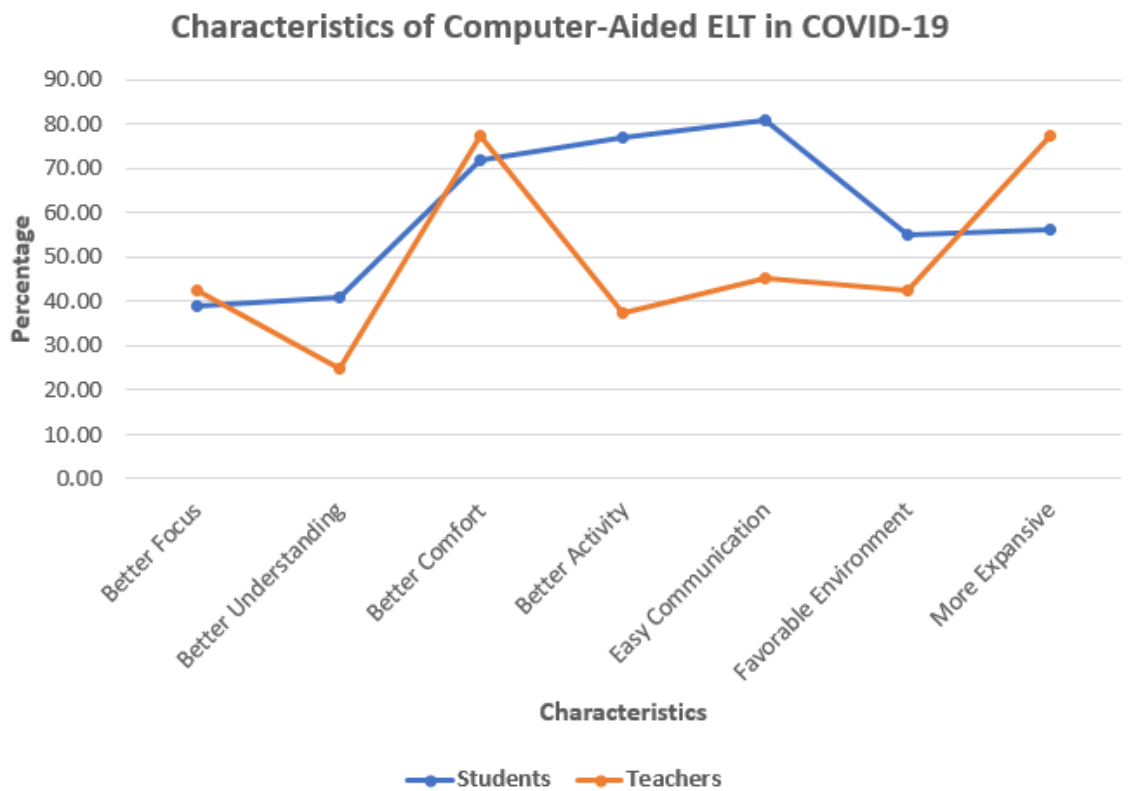

Figure 1: Characteristics of CALL in ELT

It is quite evident from Figure 1 that understanding was the biggest issue reported by teachers. Only $25 \%$ of teachers considered that understanding was not a problem in online ELT. Difficulties with understanding lecture matter and general instructions were also obvious from the collected data as only $40 \%$ of students felt that their understanding was better in online mode.

Comfort was found to be the characteristic exhibiting consensus between teachers and students. It was due to the ease of working from home. Only $39.08 \%$ of students and $42.50 \%$ of teachers felt that their focus was better in computer-aided ELT. This feature again shows significant harmony between both respondent categories.

According to $81.03 \%$ of students, communication with teachers was much easier in online mode ELT because multiple touchpoints like WhatsApp and E-Mail were available. On the contrary, the percentage of teachers who found communication easy is only $45 \%$, which is considerably low compared to that of students.

When it comes to activity and classroom environment, we found that teachers were more in favor of physical class environment even though teachers reported more comfort in working from home. $42.5 \%$ and $37.5 \%$ are the percentages of teachers who claimed that the virtual classroom environment was favorable for teaching and was more active in Elearning. Moreover, more than $77 \%$ of students testified that they were more active in online classes, which is biased, we guess, due to the psychological fears of the physical classroom environments.

A healthy percentage (77.50\%) found Computer Assisted Language Learning (CALL) more expansive in monetary 
figures. More than $56 \%$ of students also responded the same, and these numbers significantly support the fact that online education has increased overall teaching and learning expenses.

\section{Major Technical Issues Faced During Online Education}

Table 4 explores various technical problems faced by teachers and students during the online education mode. These pinpointed key issues need attention.

Table 4: Technical Issues faced during online education mode

\begin{tabular}{|c|c|c|}
\hline \multicolumn{3}{|c|}{$\begin{array}{l}\text { RQ2: What are the major technical difficulties faced by faculty as well as students in the } \\
\text { online ELT method? }\end{array}$} \\
\hline \multicolumn{3}{|l|}{ Respondent: Students } \\
\hline Sub-Questions & Agree & Disagree \\
\hline $\begin{array}{l}\text { I was not comfortable with using computer-aided tools for online } \\
\text { education. }\end{array}$ & & 72 \\
\hline I faced internet connectivity issues quite often. & 92 & 48 \\
\hline I faced audio-visual issues quite often. & 80 & 64 \\
\hline I faced no problems accessing course material. & 100 & 42 \\
\hline I faced problems in attempting an online exam. & 50 & 99 \\
\hline My pace to learn new tools was slow. & 57 & 64 \\
\hline I found learning tools enjoyable and interesting thing. & 109 & 32 \\
\hline \multicolumn{3}{|l|}{ Respondent: Teachers } \\
\hline Sub-Questions & Agree & Disagree \\
\hline $\begin{array}{l}\text { I was not comfortable with using computer-aided tools for online } \\
\text { education. }\end{array}$ & & 22 \\
\hline I faced internet connectivity issues quite often. & 28 & 10 \\
\hline I faced audio-visual issues quite often. & 29 & 7 \\
\hline I faced no problems uploading course material. & 20 & 19 \\
\hline I faced problems in designing and developing the online exam. & 25 & 8 \\
\hline My pace to learn new tools was slow. & 22 & 18 \\
\hline I found learning tools enjoyable and interesting thing. & 35 & 2 \\
\hline
\end{tabular}

Figure 2 compares problems faced by respondent categories in online ELT sessions during the ongoing pandemic. 'Learning new tools is boring' was found to be the least critical issue (only 5\% of teachers and 18.39\% students) as a substantial majority of respondents, especially teachers, liked learning new tools. By visualizing the graph, we found that the number of teachers who faced problems was considerably larger than the number of students.

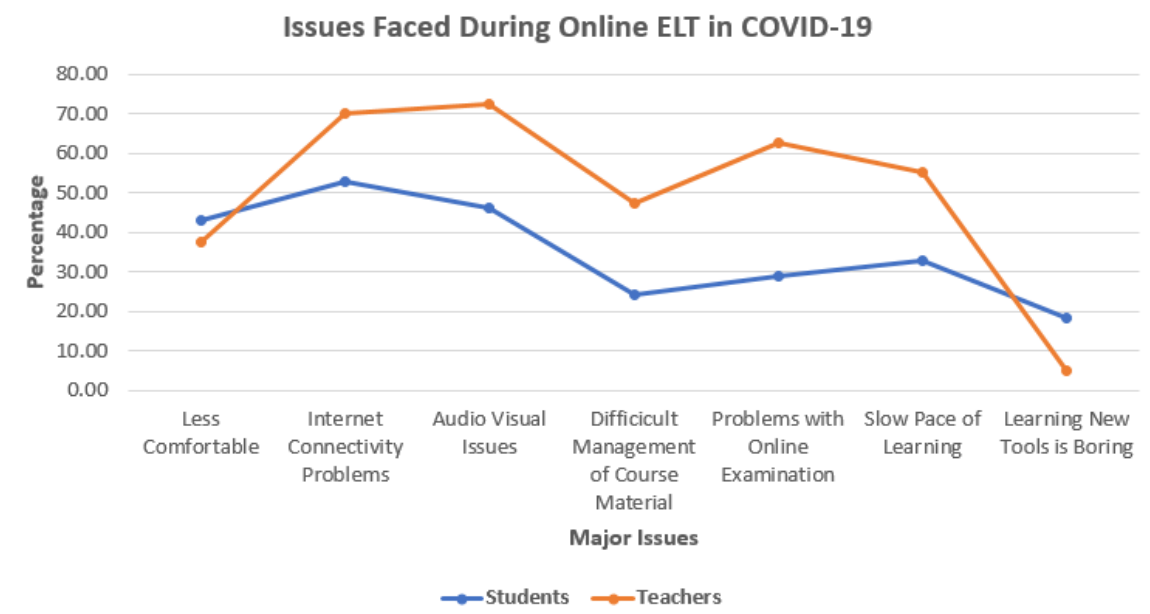

Figure 2: Technical Issues Faced During Online ELT

Source: Data Collected for our study

It was really exciting to find out that teachers found learning and working with Computer-Aided Tools interesting, yet $55 \%$ of teachers responded that their pace of learning was slow. Compared with the percentage of students (32.76\%), which was natural and consistent with teaching experience.

Internet connectivity and audio-visual problems were the most common issues faced by $70 \%$ and $72.5 \%$ of respondent teachers, respectively. $52.87 \%$ of student respondents, on the other side, reported internet connectivity as the most common issue faced during a virtual classroom environment. $62.5 \%$ of teachers found designing online exams technically 
difficult due to the inherent complexity of online examination tools like Google Forms; this suggested that maintaining transparency and supervising online exams was a difficult task.

\section{Students' assessment about teachers}

Table 5 depicts the general assessment of students about teachers during the online ELT process based on various factors.

Table 5: Assessment of teachers by students

\begin{tabular}{lll}
\hline RQ3: What was the assessment of the students about teachers during online ELT? \\
\hline Respondent: Students & Agree & Disagree \\
\hline Sub-Questions & 130 & 16 \\
\hline Lectures were well prepared. & 143 & 12 \\
\hline Teachers readily provided lecture material and learning resources. & 136 & 22 \\
\hline Teachers were punctual in taking online classes. & 153 & 3 \\
\hline The overall behavior of teachers was good during online classes. & 140 & 9 \\
\hline Instructions provided by teachers were clear and easy to understand. & 140 &
\end{tabular}

\section{Teachers' assessment about students' learning outcomes}

Students learning outcomes were one of the major factors we considered for our study. It can help us understand teachers' assessment of their students critically compared with the physical mode of ELT. Table 6 shows the evaluation made by teachers about their students during the online ELT method.

Table 6: General Assessment of students' learning outcomes

\begin{tabular}{lll}
\hline RQ4: What was the assessment of the teacher about students' learning outcomes? \\
\hline Respondent: Teachers & Agree & Disagree \\
\hline Sub-Questions & 9 & 29 \\
\hline Students participated actively during classes. & 12 & 26 \\
\hline Students submitted their assignments promptly. & 11 & 25 \\
\hline Students' participation in Quiz was active. & 11 & 25 \\
\hline $\begin{array}{l}\text { Students' examination performance was better in the online } \\
\text { examination mode. }\end{array}$ & 7 & 26 \\
\hline $\begin{array}{l}\text { Students' overall knowledge has improved during online education } \\
\text { (regardless of exam results). }\end{array}$ & 7 & 24 \\
\hline The overall behavior of students was good during online classes. & 9 & 27 \\
\hline Students were punctual in taking online classes. & 6 & 18 \\
\hline $\begin{array}{l}\text { Students were able to understand and follow your instructions } \\
\text { easily. }\end{array}$ & 14 & \\
\hline
\end{tabular}

\section{Benefits of IT in Online Education during Pandemic}

Information Technology has benefitted the modern world in every aspect of life. We have also explored different benefits perceived by respondents of this study offered by IT in the education sector. Table 7 shows various uses of incorporating IT during the pandemic as students view, while Table 8 contains benefits reported by faculty members.

Table 7: Benefits of using IT (According to Students)

\begin{tabular}{lll}
\hline RQ5: How has information technology benefitted students as second language learners? \\
\hline Respondent: Students & Agree & Disagree \\
\hline Sub-Questions & 113 & 22 \\
\hline IT has enabled you to manage your learning in a well-organized manner. & 137 & 16 \\
\hline Video, animations, and infographics have made learning more effective. & 144 & 9 \\
\hline $\begin{array}{l}\text { During online education, my searching capability on the search engine has } \\
\text { increased. }\end{array}$ & 149 & 7 \\
\hline My understanding of MS Word has improved considerably. & 143 & 9 \\
\hline $\begin{array}{l}\text { Online education has made me more efficient in working with MS } \\
\text { PowerPoint. }\end{array}$ & 145 \\
\hline $\begin{array}{l}\text { I have learned the use of online storage platforms like Google Drive during } \\
\text { a pandemic. }\end{array}$ & 138 \\
\hline I have become more proficient in using smartphones. & 12 \\
\hline $\begin{array}{l}\text { I knew only a little bit about using video conferencing tools like Google } \\
\text { Meet or Zoom before the online education model. }\end{array}$ & 137 \\
\hline $\begin{array}{l}\text { During the online education model, I have learned to diagnose technical } \\
\text { issues with my computer or mobile phone. }\end{array}$ & 123 \\
\hline
\end{tabular}


My ability to troubleshoot my computer is enhanced after switching to $106 \quad 23$ online education.

I am confident that this sort of learning has enabled me to fulfill future $125 \quad 16$ digital demands.

Table 8: Benefits of using IT (According to Teachers)

\begin{tabular}{lll}
\hline RQ6: How has information technology benefitted teachers during a pandemic? & & \\
\hline Respondent: Teachers & Agree & Disagree \\
\hline Sub-Questions & 31 & 4 \\
\hline IT has enabled you to manage your teaching in a well-organized manner. & 36 & 1 \\
\hline Video, animations, and infographics have made teaching more effective. & 37 \\
\hline $\begin{array}{l}\text { During online teaching, my searching capability on the search engine has } \\
\text { increased. }\end{array}$ & 37 & 2 \\
\hline $\begin{array}{l}\text { My understanding of MS Word has improved considerably. } \\
\text { Online teaching has made me more efficient in working with MS }\end{array}$ & 34 & 1 \\
PowerPoint. & 36 & 2 \\
\hline $\begin{array}{l}\text { I have learned the use of online storage platforms like Google Drive during } \\
\text { the pandemic. }\end{array}$ & 36 \\
\hline I have become more proficient in using smartphones. & 2 \\
\hline $\begin{array}{l}\text { I knew only a little bit about using video conferencing tools like Google } \\
\text { Meet or Zoom before online education mode. }\end{array}$ & 32 \\
\hline $\begin{array}{l}\text { During online teaching mode, I have learned to diagnose technical issues } \\
\text { with my computer or mobile phone. }\end{array}$ & 34 \\
\hline $\begin{array}{l}\text { My ability to troubleshoot my computer is enhanced after switching to } \\
\text { online teaching. }\end{array}$ & 33 \\
\hline $\begin{array}{l}\text { I am confident that this sort of learning has enabled me to fulfill future digital } \\
\text { demands. }\end{array}$ & 21 \\
\hline
\end{tabular}

Online education during a pandemic couldn't be possible without proper Information Technology (IT) support and the internet. IT has changed the entire dynamics of business, research, and education. Figure 3 shows a comparison between the respondents' perceptions regarding the benefits of IT tools in ELT.

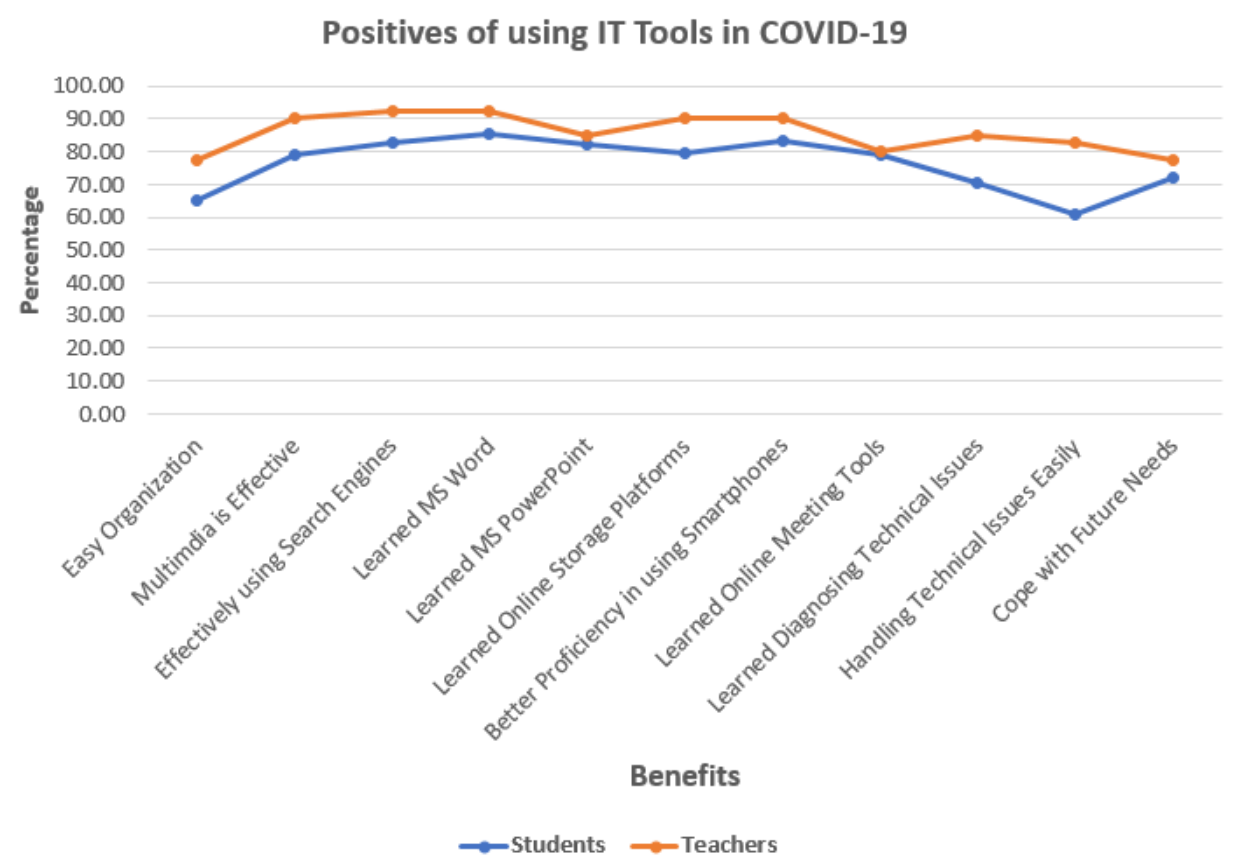

Figure 3: Comparison of Positives of IT Tools in Online Education

Figure 3 depicts that faculty have got benefitted more as compared to students. A healthy percentage of teachers (90\%) and students $(78.74 \%)$ have encouraged multimedia in online classrooms. Another encouraging factor was that both respondent categories reported increased effectiveness in using search engines and the internet during COVID-19.

Both English language teachers and second language learners who have reported that they have learned MS Word and MS PowerPoint in a virtual teaching environment were 92.5\%, 85.63\%, 82.18\%, and 85\%, which was extremely remarkable, as the respondents belonged to arts discipline. 
Online education has also improved the ability of respondents to diagnose and troubleshoot technical issues. More than $70 \%$ of respondents from both categories reported that they have become technically sound and confident enough to provide quality education online in future pandemics.

Although smartphones are common, the respondents believed their proficiency in using smartphones, apps, and online storage has enhanced. $78.74 \%$ of students and $80 \%$ of teachers were unfamiliar with online video conferencing tools before moving towards online education.

\section{How much our educational system is prepared to adopt online teaching?}

The COVID-19 outbreak has challenged the educational process. Despite ongoing vaccination, it was direly needed to assess how much our educational system is psychologically prepared for online education during future outbreaks. Table 9 shows different factors that we used for assessment.

Table 9: Preparation for Adopting Online Education

\begin{tabular}{|c|c|c|c|c|}
\hline \multicolumn{5}{|c|}{ RQ7: How much our educational system is prepared for using computer-aided tools? } \\
\hline Respondent & Studen & & Teachs & \\
\hline Sub-Questions & Agree & Disagree & Agree & Disagree \\
\hline $\begin{array}{l}\text { I prefer the active online education method for } \\
\text { learning/teaching English. }\end{array}$ & 72 & 64 & 17 & 16 \\
\hline I am prepared to learn new IT tools. & 110 & 30 & 31 & 8 \\
\hline I find it interesting to work with IT tools. & 98 & 35 & 30 & 5 \\
\hline Using IT tools creates an extra burden on me. & 62 & 74 & 24 & 9 \\
\hline $\begin{array}{l}\text { I don't have any psychological fears while working with } \\
\text { computer-aided tools. }\end{array}$ & 98 & 36 & 33 & 3 \\
\hline
\end{tabular}

Our research's primary aim was to judge the implications of computer-aided tools for online teaching and learning in view of different online classroom stakeholders; hence "Are we ready for future pandemics?" is a question that cannot be ignored. We have testified to this by considering some practical and psychological aspects of human beings.

Respondents who preferred online ELT were below 50\%, which was considerably low. Although only $22.5 \%$ of teachers claimed to be free from extra burden while working in a virtual environment yet $75 \%$ were interested in using computeraided tools yet, $77.5 \%$ showed a willingness to learn new tools in case of future pandemic outbreaks.

Psychologically, teachers $(82.5 \%)$ were highly determined to work with tools without fears compared to students $(56.32 \%)$. All these factors indicated that faculty was more mentally prepared than students, which was a healthy sign. It is depicted in Figure 4.

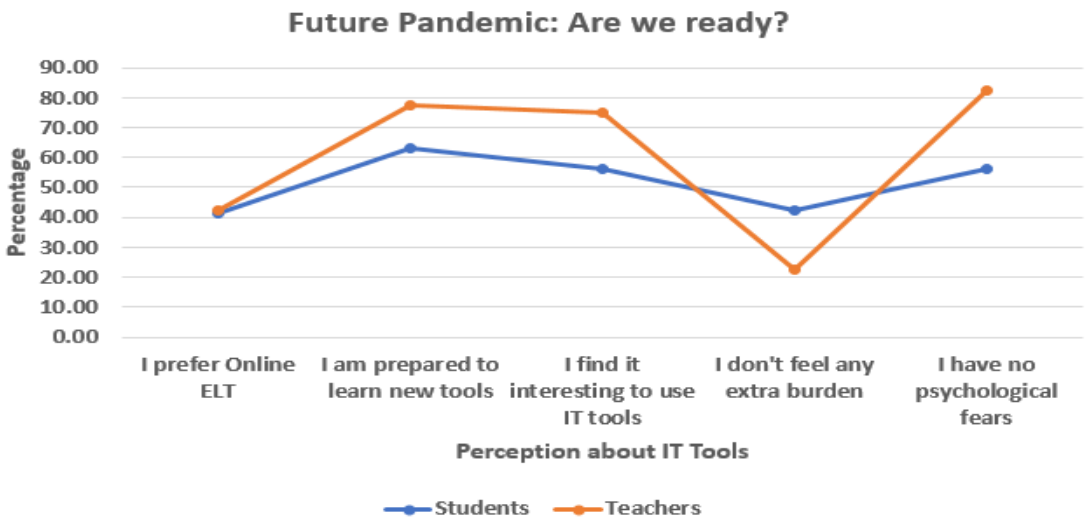

Figure 4: Readiness to Deal with Future Pandemics

\section{Suggestions to make online ELT more effective during the pandemic in Pakistan}

In this final section, our main purpose was to gather requests from faculty as well as students to tailor the current educational environment to be more effective. These suggestions were subjective, and we included these in our questionnaires as close-ended questions for better understanding. These suggestions are highlighted in Table 10.

Table 10: Suggestions from Students and Faculty

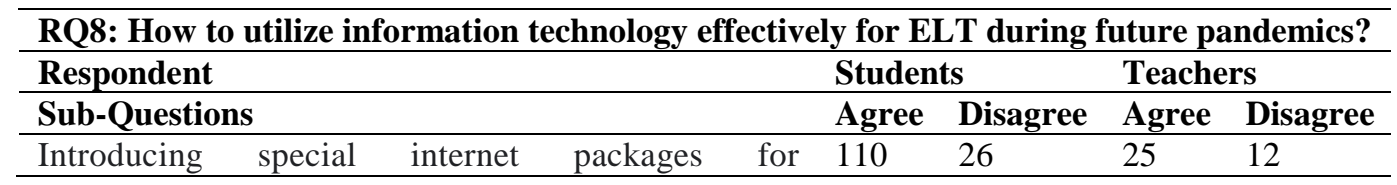




\begin{tabular}{llllll}
\hline students/teachers to lower the financial burden. & & & & 11 \\
\hline $\begin{array}{l}\text { Will the development of uniform computer-aided } \\
\text { tools for different educational institutes be more } \\
\text { beneficial? }\end{array}$ & & & & & \\
\hline $\begin{array}{l}\text { IT training programs organized at mass levels for art } \\
\text { teachers/students will be beneficial. }\end{array}$ & 115 & 11 & 25 & 11 \\
\hline $\begin{array}{l}\text { Developing dedicated portals for technical problem } \\
\text { discussion and solutions will be extremely beneficial. }\end{array}$ & 118 & 17 & 26 & 9 \\
\hline $\begin{array}{l}\text { Social media communities can facilitate computer- } \\
\text { aided ELT and learn to a great extent. }\end{array}$ & 114 & 19 & 27 & 9 \\
\hline
\end{tabular}

For coping with future pandemics effectively, certain measures are required apart from being mentally strong and working smartly with computer-aided tools for ELT. We provided respondents with some objective measures shown in Figure 5. Both respondent categories $(67.5 \%$ teachers, $65.52 \%$ students) strongly emphasized the utilization of social media for effective online ELT. Apart from this, $66.09 \%$ of students voted for mass IT training programs, and $67.82 \%$ favored the development of dedicated portals for problem sharing and discussions on computer-aided tools. The uniformity of IT tools across universities could make a huge difference in the effectiveness of online ELT education in $65 \%$ of faculty.

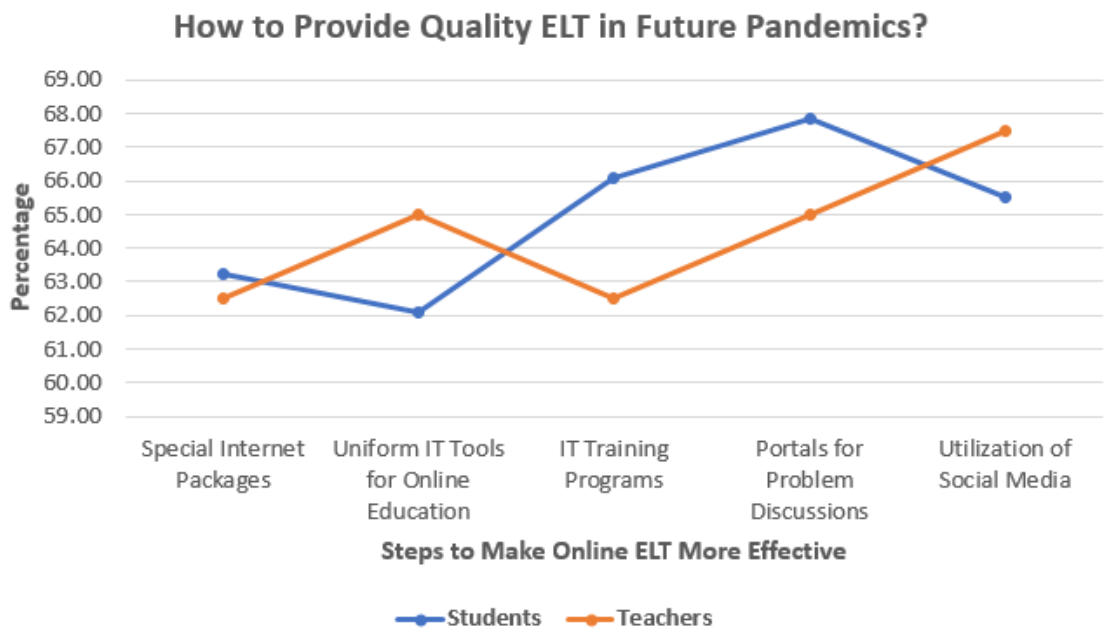

Figure 5: Improvements Needed to Cope with Future Pandemic Outbreaks

As we've discussed earlier, respondents felt that online education was expansive. More than $60 \%$ of respondents suggested that special internet packages should be announced to lower this burden and smoothening of the education process to compensate for these expenses.

Existing literature in this area considered different dimensions individually. Students' attitudes at a postgraduate level were studied generally, which highlighted technical issues faced by students in remote areas of Pakistan ( 2020). We found that there was a need to study problems faced by teachers alongside students' issues. This helped us consider critical success factors to motivate faculty staff by providing the best solutions to their problems. (Qureshi et al. 2012) found different technical barriers to E-learning in Islamabad city, well-equipped with technical knowledge, skill, workforce, and equipment. Hence, we focused our study on Faisalabad, a big one but contained many rural areas.

Moreover, our study also concentrated on the readiness of our country's education machinery to cope with future pandemic outbreaks. Furthermore, research in online ELT during pandemics focused on the targeted benefits of using ICT. But we tried to study the generic positive outcomes and improvement in general ICT awareness reported by stakeholders of the education sector in Higher Education Institutes (HEIs). English writing skills were the most critical success factor for English language learners (Shegay et al., 2020). Still, it was direly needed to find out effective ELT methods during pandemic outbreaks and equip students with the best possible skills to fulfill market needs.

\section{CONCLUSION}

Due to COVID-19, switching to online mode was entirely a new thing in Pakistan. Therefore, we conducted this research to find answers to various questions to get deep knowledge of how COVID-19 has transformed the educational sector in our country and what measures the higher education sector should take to develop improved and matured online ELT in case of future pandemic outbreaks.

Our respondents found online education more comfortable, enjoyable, and positive as compared to physical classes. It is suggestive of the fact that audio-visual multimedia and animations helped in enhancing students' interest. Respondents showed a keen interest in working with IT tools and showed a willingness to learn new tools. This was, indeed, a very 
good sign.

Another positive was the seriousness of ELT faculty despite the technical challenges faced due to lack of technical expertise. However, students were reported to be hesitant in taking an active part in academic activities. Students also showed behavioral issues and a lack of improvement in overall knowledge. Online teaching also enabled respondents to learn software tools to support online classes. Respondents' ability to diagnose and resolve technical issues was improved greatly, and respondents were sufficiently assured to be prepared for future pandemic situations.

However, to deal with future outbreaks, certain measures could be taken to improve current online ELT and education.

\section{LIMITATION OF THIS STUDY AND FUTURE DIRECTIONS}

The respondents of this research study belonged to the English department in various public, private and semigovernment institutes in Faisalabad. Although data was reliable yet, there is a need for a full-fletched exploratory study comprising a population of different areas, including northern urban and rural areas where IT infrastructure and facilities are different compared with technologically equipped and advanced cities of Pakistan. In the future, we aim to extend this research on ELT for science students in universities and affiliated colleges.

\section{AUTHORS CONTRIBUTION}

Faiza Saeed choose ELT as her main area of research and conducted a study on emerging and existing ELT methods on college students in Faisalabad. She explored the internet and reviewed the literature to find out this research gap as it was in need of time. She also identified research questions and designed a questionnaire. Aniqa Rashid supervised the whole research task. Wajiha Saleem performed data analysis and discussed the finding. Muhammad Sufyan Afzal worked on data collection from respondents.

\section{REFERENCES}

1. Unsworth, L. and Mills, K. A. (2020). English language teaching of attitude and emotion in digital multimodal composition. Journal of Second Language Writing, 47(100712), 1-17. https://doi.org/10.1016/j.jslw.20 20.100712

2. Zhiyong, S., Muthukrishnan, P. and Sidhu, G. K. (2020). College English Language Teaching Reform and Key Factors Determining EFL Teachers' Professional Development. European Journal of Educational Research, 9(4), 1393-1404. https://doi.org/10.12973/eu-jer.9.4.1393

3. Jena, P. K. (2020). Impact of Pandemic COVID-19 on Education in India. International Journal of Current Research, 12(7), 12582-12586. https://doi.org/10.31235/osf.io/2kasu

4. Asad, M. M., Hussain, N., Wadho, M., Khand, Z. H., and Churi, P. P. (2020). Integration of E-learning Technologies for Interactive Teaching and Learning Process: An Empirical Study on Higher Education Institutes of Pakistan. Journal of Applied Research in Higher Education, 13(3), 649-663. https://doi.org/10.1108/JARHE04-2020-0103

5. Khamkhein, A. (2012). Computer Assisted Language Learning and English Language Teaching in Thailand: Overview. Mediterranean Journal of Social Sciences, 3(1), 55-64.

6. Shahzad, K. S., Hussain, J., Sadaf, N., Sarwat, S., Ghani, U., and Saleem, R. (2020). Impact of Virtual Teaching on ESL Learners' Attitude under Covid-19 Circumstances at Post Graduate Level in Pakistan. Journal of English Language Teaching Canadian Center of Science and Education, 9(13), 1-9. https://doi.org/10.5539/elt.v13n9p1

7. Nawaila, M. B., Kanbul, S., and Alhamroni, R. (2020). Technology and English Language Teaching and Learning: A Content Analysis. Journal of Learning and Teaching in Digital Age, 5(1), 16-23.

8. Sathya, P. (2017). A Study on Digital Marketing and its Impact. International Journal of Science and Research, 6(2), 866-868.

9. Shah, K. S., and Saeed, F. (2015). Teachers' Beliefs and Students' Motivation about Emerging and Existing Methods of English Language Teaching: A Case Study of Intermediate Teachers and Students of Faisalabad. Journal of Literature, Language and Linguistics, 8(1), 17-21.

10. Shegay, A., Orazova, F. and Krivosheeva, G. (2020). Possible Writing Techniques while Teaching for Students whose English is a Foreign Language. European Journal of Research and Reflection in Educational Sciences, $8(6), 69-72$.

11. Ittefaq, M. and Iqbal, A. (2018). Digitization of the health sector in Pakistan: challenges and opportunities to online health communication: A case study of MARHAM social and mobile media. Digital Health, 4(2018), 113. https://doi.org/10.1177/2055207618789281

12. Portnoy, J., Waller, M., and Elliot, T. (2020). Telemedicine in the Era of COVID-19. The Journal of Allergy and Clinical Immunology: In Practice, 8(5), 1489-1491. https://doi.org/10.1016/j.jaip.2020.03.008

13. Asrifan, A., Zita, C. T., Vargheese, K. J., Syamsu, T. and Amir, M. (2020). The Effects of CALL (Computer Assisted Language Learning) Toward the Students' English Achievement and Attitude. Journal of Advanced English Studies, 3(2), 94-106.

14. Mishra, L., Gupta, T., and Shree, A. (2020). Online teaching-learning in higher education during lockdown period of COVID-19 pandemic. International Journal of Educational Research Open, 1(2020). https://doi. org/10.1016/j.ijedro.2020.100012 
15. DeWitt, D., Alias, N., Siraj, S., Yaakub, M. Y., Ayob, J. and Ishak, R. (2013). The potential of Youtube for teaching and learning in the performing arts. In Proceedings of 13th International Educational Technology Conference, 103(2013), 1118-1126. https://doi.org/10.1016/j.sbspro.2013.10.439

16. Islam, M., Karim, D. A. and Kwon, M. (2020). A Comparison of Two Forms of Instruction: Pre-Recorded Video Lectures vs. Live ZOOM Lectures for Education in the Business Management Field. Sustainability, 12(19), 8149. https://doi.org/10.3390/su12198149

17. Ulla, M. B., Perales, W. F. and Tarrayo, V. N. (2020). Integrating Internet-based applications in English language teaching: Teacher practices in a Thai university. Issues in Educational Research, 30(1), 365-378.

18. Quinn, M. and Clark, S. K. (2015). Adopting online lecturing for improved learning: A case study from teacher education. Journal of University Teaching \& Learning Practice, 12(3), 1-19.

19. Hadgu, R. M., Huynh, S. H. V. and Gopalan, C. (2016). The Use of Pre-Recorded Lectures on Students Performance in Physiology. Journal of Curriculum and Teaching, 5(1), 105-112. https://doi.org/10.5430/jc t.v5n1p105

20. Bakar, N. A. (2007). English Language Activities in Computer-Based Learning Environment: A Case Study in ESL Malaysian Classroom. GEMA Online Journal of Language Studies, 7(1), 33-49.

21. Qureshi, I. A., Ilyas, K., Yasmin, R., and Witty, M. (2012). Challenges of implementing e-learning in a Pakistani university. Knowledge Management \& E-Learning: An International Journal, 4(3), 310-324. https://doi.org/10. 34105/j.kmel.2012.04.025

22. Raza, S., Umer, A., Qazi, W., and Makhdoom, M. (2017). The Effects of Attitudinal, Normative, and Control Beliefs on M-Learning Adoption Among the Students of Higher Education in Pakistan. Journal of Educational Computing Research, 56(4), 563-588. https://doi.org/10.1177/0735633117715941

23. Rahim, S., SunTie, D., Begum, A., and Sahar, G. (2011). ICTs in Education for the Mountainous Area Development: An Application Based Study of Gilgit (Pakistan). In Education and Educational Technology, Springer, Berlin, 73-79. https://doi.org/10.1007/978-3-642-24775-0_11

24. Milal, A., Rohmah, Z. and Kusumajanti, W. (2020). Varying strategies to maximize the effectiveness of ELT: Lessons from training sessions. English Language Teaching Educational Journal, 3(3), 263-271.

25. Schurz, A. and Coumel, M. (2020). Grammar teaching in ELT: A cross-national comparison of teacher-reported practices. Language Teaching Research, 1-26. https://doi.org/10.1177/1362168820964137

26. Pervaiz, A., Rana, A. M. K., Bashir, I., and Batool, N. (2021). Exploring the Writing Techniques of ELT Practitioners in Private and Public Schools. International Journal of Innovation, Creativity, and Change, 15(3), 823-837.

27. Sultan, A. and Hameed, A. (2020). From Global to Glocal: An Investigation of Pakistan Military Academy Students' Perspective on Cultural Aspects in English Language Pedagogy. Pakistan Journal of Distance \& Online Learning, 6(1), 65-83.

28. Soomro, M. A., Ahmed, A., Siming, I. A., Rajper, M. A., and Malik, S. (2020). Towards Investigation of Instructional "Hiccups" of ELT Fraternity in EFL Classroom. Journal of Language and Culture Education, 8(3), 75-86. https://doi.org/10.2478/jolace-2020-0021

29. Irfan, F., Abbas, F., Talib, N., and Hussain, T. (2020). Analyzing English Language Teaching-Learning Process in Public Sector Schools in Pakistan. Psychology and Education Journal, 57(9), 5328-5344.

30. Kosten, J. B. (2020). The mono-lingual problem of computer-assisted language learning. ReCALL, 32(3), 307322. https://doi.org/10.1017/S095834402000004X

31. Enayati, F. and Gilakjani, A. P. (2020). The Impact of Computer Assisted Language Learning (CALL) on Improving Intermediate EFL Learners' Vocabulary Learning. International Journal of Language Education, 4(1), 96-112. https://doi.org/10.26858/ijole.v4i2.10560

32. Taber, K. S. (2018). The Use of Cronbach's Alpha When Developing and Reporting Research Instruments in Science Education. Res Sci Educ, 48, 1273-1296. https://doi.org/10.1007/s11165-016-9602-2 